\title{
Novel Nanocomposite of Chitosan-protected Platinum Nanoparticles Immobilized on Nickel Hydroxide: Facile Synthesis and Application as Glucose Electrochemical Sensor
}

\author{
DEJIANG RAO, QINGLIN SHENG and JIANBIN ZHENG* \\ Institute of Analytical Science, Shaanxi Provincial Key Laboratory of Electroanalytical Chemistry, \\ Northwest University, Xi' an, Shaanxi 710069, China \\ e-mail: zhengjb@nwu.edu.cn
}

MS received 6 May 2016; revised 17 June 2016; accepted 22 July 2016

\begin{abstract}
Novel nanocomposite of nickel hydroxide/chitosan/platinum was successfully synthesised with chitosan (CS) as a dispersing and protecting agent. Its potential application in non-enzymatic electrochemical glucose sensor was studied. Scanning electron microscopy (SEM), transmission electron microscopy (TEM) and energy-dispersive X-ray spectroscopy (EDX) were used to characterize the composition and morphology of this nanocomposite. The electrochemical investigations of this glucose sensor exhibited remarkable analytical performances towards the oxidation of glucose. In particular, glucose can be selectively and sensitively detected in a wide linear range from $3.0 \times 10^{-6}$ to $1.1 \times 10^{-2} \mathrm{~mol} \cdot \mathrm{L}^{-1}$ with a detection limit of $0.56 \pm 0.03 \mu \mathrm{mol} \cdot \mathrm{L}^{-1}$ at a signal-tonoise ratio of $3(\mathrm{~S} / \mathrm{N}=3)$. Furthermore, the $\mathrm{Ni}(\mathrm{OH})_{2} / \mathrm{CS} / \mathrm{Pt}$ nanocomposite-modified GCE also showed an acceptable anti-interference ability and stability. Importantly, the $\mathrm{Ni}(\mathrm{OH})_{2} / \mathrm{CS} / \mathrm{Pt}$ based sensor can be used to detect trace amount of glucose in serum samples. The results demonstrated that the $\mathrm{Ni}(\mathrm{OH})_{2} / \mathrm{CS} / \mathrm{Pt}$ nanocomposite can be potentially useful to construct a new glucose sensing platform.
\end{abstract}

Keywords. Electrochemical sensor; platinum nanoparticles; nickel hydroxide; glucose; chitosan.

\section{Introduction}

Early and precise detection of blood glucose levels can reduce a lot of risk to multiple organs especially the eyes, heart and blood vessels. ${ }^{1}$ There are various methods to determine the concentration of glucose, such as colorimetry, ${ }^{2}$ capacitive detection, ${ }^{3}$ electrochemiluminescence and electrochemical methods., ${ }^{4,5}$ Among these methods, electrochemical detection methods are attracting more and more attention because of their simplicity, cost-effectiveness and efficiency. ${ }^{6}$ Baghayeri et al., reported a non-enzymatic glucose sensor based on Ag nanoparticle-decorated, functionalized carbon nanotubes, and it exhibited a low detection limit of $0.0003 \mu \mathrm{M}(\mathrm{S} / \mathrm{N}=3){ }^{7}$ The non-enzymatic and enzyme-based electrochemical sensors are used as two different strategies to detect glucose concentration in recent years. However, enzyme-based electrochemical sensors are limited by two main problems involving complex fabrication procedure and poor stability. ${ }^{8,9}$ As a result, the non-enzymatic electrochemical method seems to be a preferred measurement technique. In addition, good catalytic properties of nanomaterials

*For correspondence have aided in the development of non-enzymatic electrochemical sensors. ${ }^{10,11}$ Recently, many nanomaterials have been reported and applied to the non-enzymatic electrochemical glucose sensors. Noble metal nanoparticles (NPs), e.g., platinum and gold, as the electrocatalyst have been widely used for electrochemical detection of glucose because of their unique physical and chemical properties. ${ }^{12-15}$ In particular, owing to the excellent electrocatalytic properties and good conductivity of Pt NPs, they have stimulated considerable research and development of electrochemical sensors. ${ }^{16,17}$

Recently, many Pt-based nanocomposites were proposed for improved glucose electrochemical sensing platforms. ${ }^{18,19}$ However, the properties of nanomaterials are related to their size..$^{20,21}$ In order to prevent the agglomeration of the nanomaterials, it is essential to have a support medium for the particles to remain dispersed. $\mathrm{Ni}(\mathrm{OH})_{2}$ has been widely used as an electrocatalyst for the development of electrochemical sensors including glucose sensors because of its good electrocatalytic properties and low cost. ${ }^{22,23}$ Chen et al., reported a glucose electrochemical sensor by immobilizing $\mathrm{Ni}(\mathrm{OH})_{2} / \mathrm{Au}$ catalyst on GCE, and it showed good analytical properties with a detection limit of 0.92 
$\mu \mathrm{M}(\mathrm{S} / \mathrm{N}=3) .{ }^{24}$ Meanwhile, chitosan (CS) has many characteristics, including excellent film-forming ability, good adhesion, biocompatibility and non-toxicity. ${ }^{25,26}$ In addition to the above, the presence of plenty of amino and hydroxyl groups allow it to be applied in chemical modification. ${ }^{27,28}$ Therefore, Pt NPs can be easily reduced to the surface of $\mathrm{Ni}(\mathrm{OH})_{2}$ using $\mathrm{CS}$ as both a coupling agent and a dispersing agent. ${ }^{29}$ According to what we have known, CS was rarely used in the preparation of well-dispersed Pt NPs. Bai et al., fabricated a composite containing CS-Pt nanoparticles and carbon nanotubes-doped phosphomolybdate, and then they studied its electrochemical properties towards the oxidation of nitrite. ${ }^{30}$

Herein, the $\mathrm{Ni}(\mathrm{OH})_{2} / \mathrm{CS} / \mathrm{Pt}$ nanocomposite was successfully synthesized with CS as a dispersing and protecting agent. A glucose electrochemical sensor was developed by modifying the $\mathrm{Ni}(\mathrm{OH})_{2} / \mathrm{CS} / \mathrm{Pt}$ nanocomposite onto a GCE. In particular, this sensor presents a wide linear range and low detection limit. The construction of the $\mathrm{Ni}(\mathrm{OH})_{2} / \mathrm{CS} / \mathrm{Pt} / \mathrm{GCE}$ is shown in Scheme 1.

\section{Experimental}

\subsection{Reagents and chemicals}

$\mathrm{Ni}\left(\mathrm{NO}_{3}\right)_{2} \cdot 6 \mathrm{H}_{2} \mathrm{O}, \mathrm{NaOH}$ and urea were obtained from Tianjin Tianli Chemistry Reagent Co., Ltd (Tianjin, China); $\mathrm{NaBH}_{4}$ was purchased from Guangdong Guanghua Chemical Factory Co., Ltd. (Guangdong, China); dopamine and CS (MW 5-6×105, >90\% deacetylation) were purchased from Shanghai Yuanju Biotechnology Co., Ltd. (Shanghai, China); chloroplatinic acid $\left(\mathrm{H}_{2} \mathrm{PtCl}_{6} \cdot \mathrm{H}_{2} \mathrm{O}\right)$ was acquired from Shanghai Reagent Factory (Shanghai, China). All other reagents used in this work were of analytical grade. All aqueous solutions were prepared with doubly distilled water.

\subsection{Apparatus and Electrochemical Measurements}

Transmission electron microscopy (TEM) and highresolution transmission electron microscopy (HRTEM) images were obtained by using a Teenai G2 F20 STWIN (FEI, USA) microscope. The images of scanning electron microscopy (SEM) and the patterns of energydispersive X-ray spectroscopy (EDX) were recorded on a JSM-6700F (JEOL, Japan) microscope. All electrochemical experiments were conducted using an electroanalysis system of CHI 660 electrochemical workstation (Shanghai CH Instrument Co., Ltd., China) with a conventional three-electrode cell. The bare GCE (diameter: $3.0 \mathrm{~mm}), \mathrm{Ni}(\mathrm{OH})_{2}$ modified $\mathrm{GCE}\left(\mathrm{Ni}(\mathrm{OH})_{2} / \mathrm{GCE}\right)$, $\mathrm{Ni}(\mathrm{OH})_{2} / \mathrm{CS}$ modified $\mathrm{GCE}\left(\mathrm{Ni}(\mathrm{OH})_{2} / \mathrm{CS} / \mathrm{GCE}\right)$ and $\mathrm{Ni}(\mathrm{OH})_{2} / \mathrm{CS} / \mathrm{Pt}$ modified GCE $\left(\mathrm{Ni}(\mathrm{OH})_{2} / \mathrm{CS} / \mathrm{Pt} / \mathrm{GCE}\right)$ were all used as working electrodes. The geometric surface area of GCE is $0.071 \mathrm{~cm}^{2}$. A saturated calomel electrode ( $\mathrm{SCE}, \mathrm{Pt}|\mathrm{Hg}(\mathrm{l})| \mathrm{Hg}_{2} \mathrm{Cl}_{2}(\mathrm{~s}) \mid \mathrm{KCl}$ ) and platinum wire were used as the reference electrode and counter electrode, respectively. All experiments were conducted at room temperature $\left(25 \pm 2^{\circ}\right)$.

\subsection{Fabrication of the Sensor}

2.3a Synthesis of $\mathrm{Ni}(\mathrm{OH})_{2}: \mathrm{Ni}(\mathrm{OH})_{2}$ was prepared by the reported method. ${ }^{31}$ Briefly, $3.6 \mathrm{~g}$ of $\mathrm{Ni}\left(\mathrm{NO}_{3}\right)_{2} \cdot 6 \mathrm{H}_{2} \mathrm{O}$ was dissolved in $25 \mathrm{~mL}$ of doubly distilled water. Then, $6 \mathrm{~g}$ of urea was added and the solution was stirred for $1 \mathrm{~h}$. After transferring the mixture into a $25 \mathrm{~mL}$ Teflon-lined autoclave, it was heated to $120^{\circ} \mathrm{C}$ and then kept at this temperature for $2 \mathrm{~h}$. The autoclave was then allowed to cool to room temperature
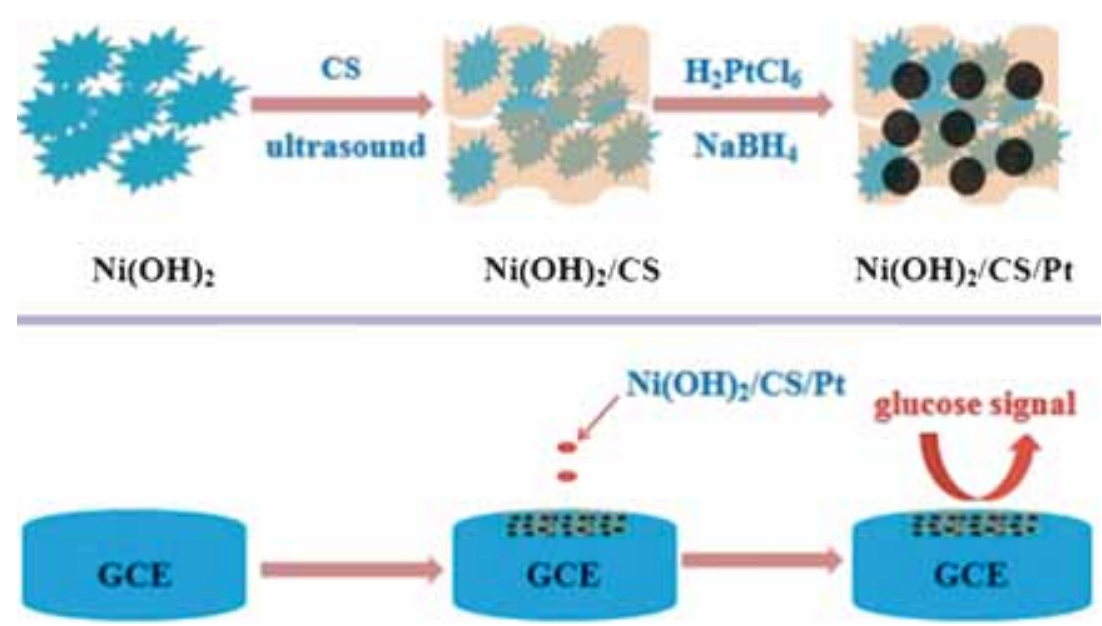

Scheme 1. Schematic illustration for the preparation of $\mathrm{Ni}(\mathrm{OH})_{2} / \mathrm{CS} / \mathrm{Pt} / \mathrm{GCE}$. 
at the end of the reaction. The final products were centrifuged, washed several times with doubly distilled water, and then dried in an oven at $80^{\circ} \mathrm{C}$ for $6 \mathrm{~h}$.

2.3b Synthesis of $\mathrm{Ni}(\mathrm{OH})_{2} / \mathrm{CS} / \mathrm{Pt}$ nanocomposites: $\mathrm{Ni}(\mathrm{OH})_{2}$ powder $(20 \mathrm{mg})$ was added to $40 \mathrm{~mL}$ of ethanol-water $(1: 1, \mathrm{v} / \mathrm{v}$ ratio) solution, and the mixture was ultrasonicated for $30 \mathrm{~min}$. Following this, $2.0 \mathrm{~mL}$ of CS $(0.5 \mathrm{wt} \%)$ was added and the solution was further ultrasonicated for $60 \mathrm{~min}$. Next, $500 \mu \mathrm{L}$ of $\mathrm{H}_{2} \mathrm{PtCl}_{6}$ solution $(10 \mathrm{mM})$ was added to the mixture before being ultrasonicated. After stirring for $30 \mathrm{~min}, 800 \mu \mathrm{L}$ of 10 $\mathrm{mM} \mathrm{NaBH}_{4}$ solution was subsequently added dropwise under constant stirring. The reaction was carried out at room temperature for $3 \mathrm{~h}$. The composite product was collected by centrifugation, washed with doubly distilled water three times, and then dried at $50^{\circ} \mathrm{C}$ for $8 \mathrm{~h}$. To obtain the $\mathrm{Ni}(\mathrm{OH})_{2} / \mathrm{CS}$ composites, the above synthetic procedure was repeated in the absence of $\mathrm{H}_{2} \mathrm{PtCl}_{6}$ and $\mathrm{NaBH}_{4}$.

2.3c Electrode modification: Prior to electrode modification, the GCE was polished to a mirror finish using 1.0 and $0.3 \mu \mathrm{m}$ alumina powder. The GCE was washed with doubly distilled water, and then ultrasonicated in $20 \mathrm{~mL}$ of ethanol-water $(1: 1, \mathrm{v} / \mathrm{v}$ ratio) solution. The prepared GCE was dried in a stream of nitrogen. After that, $1.0 \mathrm{mg}$ of $\mathrm{Ni}(\mathrm{OH})_{2} / \mathrm{CS} / \mathrm{Pt}$ nanocomposites was ultrasonically dispersed in $1.0 \mathrm{~mL}$ of CS (wt\%, $0.1 \%$ ) solution for $30 \mathrm{~min}$. The obtained suspension $(5 \mu \mathrm{L})$ was applied to the GCE surface and dried in air at room temperature. The modified electrode was labelled as $\mathrm{Ni}(\mathrm{OH})_{2} / \mathrm{CS} / \mathrm{Pt} / \mathrm{GCE}$.

\section{Results and Discussion}

\subsection{Characterization of $\mathrm{Ni}(\mathrm{OH})_{2} / \mathrm{CS} / \mathrm{Pt}$ \\ Nanocomposites}

The morphology and microstructure of the obtained samples were observed by SEM, TEM and HRTEM. Figure 1 shows the SEM images of $\mathrm{Ni}(\mathrm{OH})_{2}(\mathrm{~A})$, $\mathrm{Ni}(\mathrm{OH})_{2} / \mathrm{CS}$ composites (B), TEM images of $\mathrm{Ni}(\mathrm{OH})_{2}$ (C), $\mathrm{Ni}(\mathrm{OH})_{2} / \mathrm{CS}$ composites (D), $\mathrm{Ni}(\mathrm{OH})_{2} / \mathrm{CS} / \mathrm{Pt}$ nanocomposites (E) and HRTEM image of Pt NPs (F). As shown in Figures $1 \mathrm{~A}$ and $\mathrm{C}$, the particulate $\mathrm{Ni}(\mathrm{OH})_{2}$ microparticles with a diameter of $160 \pm 30 \mathrm{~nm}$ were observed. It can be observed from Figure 1B that CS films were modified on the surface of $\mathrm{Ni}(\mathrm{OH})_{2}$ particles and the particulate features of $\mathrm{Ni}(\mathrm{OH})_{2}$ became blurred. The obvious CS polymer film combined with particulate $\mathrm{Ni}(\mathrm{OH})_{2}$ microparticles was observed in Figure 1B. As illustrated in Figure 1C, in the presence of CS, the boundary among the $\mathrm{Ni}(\mathrm{OH})_{2}$ particles is not so clear. Figure 1E indicates that the Pt NPs were deposited on the surface of $\mathrm{Ni}(\mathrm{OH})_{2} / \mathrm{CS}$ composites. As demonstrated in Figure 1F, the HRTEM of Pt NPs clearly displays the diameter of individual nanoparticle to be $8 \pm$ $3 \mathrm{~nm}$. Importantly, the Pt NPs with no obvious aggregation were observed by this synthetic strategy of CS as a dispersing and protecting agent.

EDX analysis can reveal the elemental composition of the nanocomposites. EDX patterns of $\mathrm{Ni}(\mathrm{OH})_{2} / \mathrm{CS} / \mathrm{Pt}$
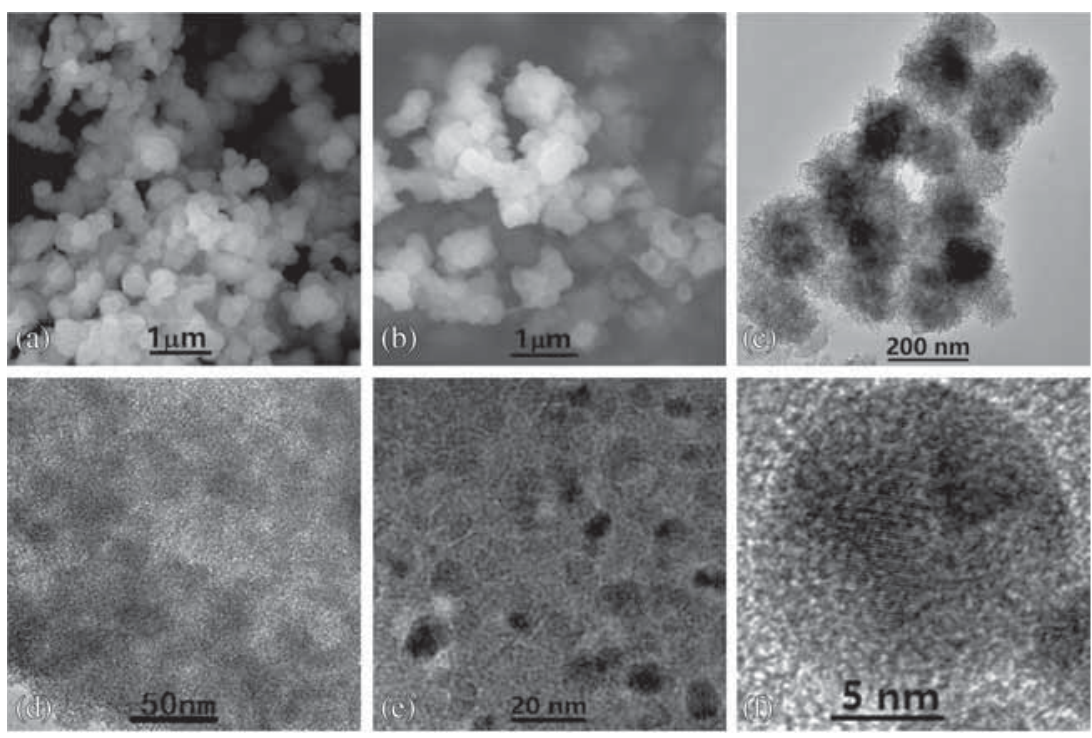

Figure 1. The SEM images of $(\mathrm{A}) \mathrm{Ni}(\mathrm{OH})_{2} ;(\mathrm{B}) \mathrm{Ni}(\mathrm{OH})_{2} / \mathrm{CS}$ composites; (C) TEM images of $\mathrm{Ni}(\mathrm{OH})_{2}$; (D) $\mathrm{Ni}(\mathrm{OH})_{2} / \mathrm{CS}$ composites; (E) $\mathrm{Ni}(\mathrm{OH})_{2} / \mathrm{CS} / \mathrm{Pt}$ nanocomposites; (F) HRTEM image of Pt NPs. 
(Figure 2) indicated that the nanocomposite was composed of Ni, O, N and Pt elements without any other metal catalysts or additives. These results indicated that the $\mathrm{Ni}(\mathrm{OH})_{2} / \mathrm{CS} / \mathrm{Pt}$ nanocomposites have been successfully synthesized by this method.

\subsection{Electrochemical behavior of $\mathrm{Ni}(\mathrm{OH})_{2} / \mathrm{CS} / \mathrm{Pt}$}

Electrochemical impedance spectroscopy (EIS) is an effective tool for studying the performance of surface modified electrodes. In general, the diameter of a semicircle in the high frequency region of Nyquist plot represents the electron transfer resistance $\left(\mathrm{R}_{\mathrm{et}}\right){ }^{32}$ Figure 3 shows the Nyquist plots of (a) the bare GCE, (b) $\mathrm{Ni}(\mathrm{OH})_{2} / \mathrm{GCE}$, (c) $\mathrm{Ni}(\mathrm{OH})_{2} / \mathrm{CS} / \mathrm{GCE}$ and (d) $\mathrm{Ni}(\mathrm{OH})_{2} / \mathrm{CS} / \mathrm{Pt} / \mathrm{GCE}$ in $0.10 \mathrm{~mol} \mathrm{~L}^{-1} \mathrm{NaOH}$ solution containing $5.0 \mathrm{mM}\left[\mathrm{Fe}(\mathrm{CN})_{6}\right]^{4-/ 3-}$ at open-circuit potential conditions with frequency range from $0.01 \mathrm{~Hz}$ to $10 \mathrm{kHz}$. As shown in Figure 3, the $\mathrm{R}_{\mathrm{et}}$ obtained at the bare GCE shows a very small semicircle diameter. After comparing the data, the values of $\mathrm{R}_{\mathrm{et}}$ for different working electrodes are arranged in the following sequence: $\mathrm{Ni}(\mathrm{OH})_{2} / \mathrm{CS} / \mathrm{GCE}(2465.6 \Omega)>\mathrm{Ni}(\mathrm{OH})_{2} / \mathrm{GCE}(1712.2$ $\Omega)>\mathrm{Ni}(\mathrm{OH})_{2} / \mathrm{CS} / \mathrm{Pt} / \mathrm{GCE}(695.5 \Omega)>\operatorname{GCE}(373.9$ $\Omega$ ). The semicircle of $\mathrm{Ni}(\mathrm{OH})_{2} / \mathrm{CS} / \mathrm{Pt} / \mathrm{GCE}$ (trace d) was smaller than other modified electrode (trace b, c). $R_{\text {et }}$ estimated from trace $d$ is $46.2 \%$ larger than that from trace a. These results demonstrated that Pt NPs can effectively enhance the efficiency of electron transfer.

Figures $4 \mathrm{~A}$ and $4 \mathrm{~B}$ show the cyclic voltammograms (CVs) of $0.1 \mathrm{M} \mathrm{NaOH}$ at a bare GCE, $\mathrm{Ni}(\mathrm{OH})_{2} / \mathrm{GCE}$ and $\mathrm{Ni}(\mathrm{OH})_{2} / \mathrm{CS} / \mathrm{Pt} / \mathrm{GCE}$, respectively. The red arrow in all CVs indicates the direction of sweep. As shown in Figure 4B, a pair of well-defined redox peaks was observed in the $\mathrm{CVs}$ of the $\mathrm{Ni}(\mathrm{OH})_{2} / \mathrm{GCE}$, which

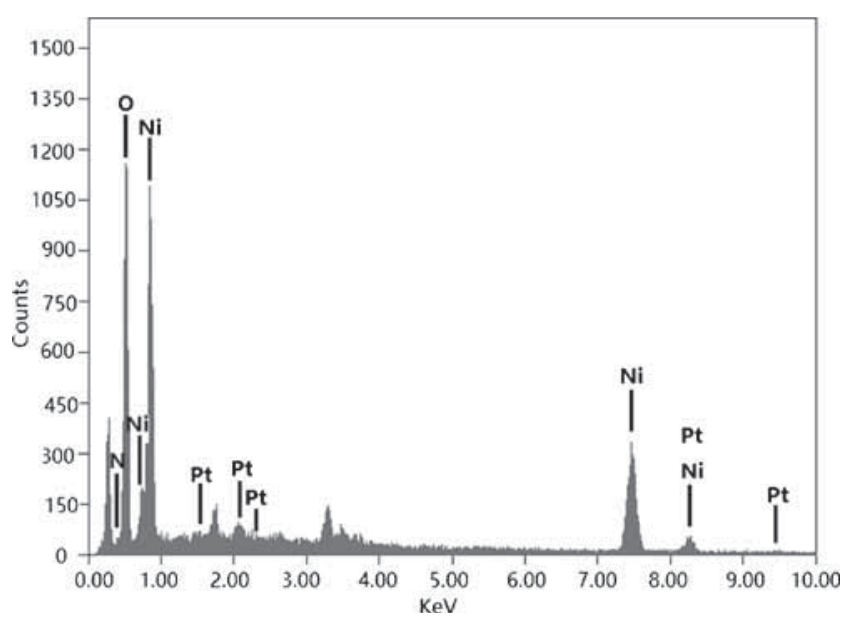

Figure 2. EDX patterns of $\mathrm{Ni}(\mathrm{OH})_{2} / \mathrm{CS} / \mathrm{Pt}$ nanocomposites on conductive glass coated with indium tin oxide (ITO). belong to the oxidation of $\mathrm{Ni}(\mathrm{OH})_{2}(\mathrm{Ni}(\mathrm{II}))$ in alkaline medium to $\mathrm{NiOOH}(\mathrm{Ni}(\mathrm{III})){ }^{33}$ It is clear from the Figures that the pronounced oxidation peak current is observed. It is obviously seen that $\mathrm{Ni}(\mathrm{OH})_{2} / \mathrm{GCE}$ (curve c) and $\mathrm{Ni}(\mathrm{OH})_{2} / \mathrm{CS} / \mathrm{Pt} / \mathrm{GCE}$ (curve e) exhibited low anodic peak current $\left(I_{p a}\right)$ and cathodic peak current $\left(I_{p c}\right)$ in the absence of glucose in $0.1 \mathrm{M} \mathrm{NaOH}$ solution. However, for the $\mathrm{Ni}(\mathrm{OH})_{2} / \mathrm{CS} / \mathrm{Pt} / \mathrm{GCE}$, the obvious increase of anodic peak current was observed in $0.1 \mathrm{M} \mathrm{NaOH}$ solution after the addition of $3.0 \mathrm{mM}$ glucose (curve f). The bare GCE (curve b) and $\mathrm{Ni}(\mathrm{OH})_{2} /$ GCE (curve d) exhibited low electrochemical responses after the addition of $3.0 \mathrm{mM}$ glucose. Compared with $\mathrm{Ni}(\mathrm{OH})_{2} / \mathrm{GCE}$ (curve d), the $I_{p a}$ of $\mathrm{Ni}(\mathrm{OH})_{2} / \mathrm{CS} / \mathrm{Pt} / \mathrm{GCE}$ (curve $\mathrm{f}$ ) showed an increase of 85.2 percent from 27 to $50 \mu \mathrm{A}$. The $\mathrm{Ni}(\mathrm{OH})_{2} / \mathrm{CS} / \mathrm{Pt} / \mathrm{GCE}$ showed an apparent anodic current peak of $\sim 50 \mu \mathrm{A}$ at nearly $0.43 \mathrm{~V}$. These results indicate that the $\mathrm{Ni}(\mathrm{OH})_{2} / \mathrm{CS} / \mathrm{Pt}$ nanocomposites exhibit a good and effective catalytic performance for the oxidation of glucose.

In order to improve the analytical characteristics of this glucose sensor, we investigated the effect of $\mathrm{NaOH}$ concentration $\left(\mathrm{C}_{\mathrm{NaOH}}, 0.04,0.06,0.08,0.10\right.$, $0.12,0.14$ and $\left.0.16 \mathrm{~mol} \cdot \mathrm{L}^{-1}\right)$ on the oxidation peak current of glucose $(3.0 \mathrm{mM})$ by cyclic voltammetry at the $\mathrm{Ni}(\mathrm{OH})_{2} / \mathrm{CS} / \mathrm{Pt} / \mathrm{GCE}$. The results are shown in Figure $\mathrm{S} 1$ of Supplementary Information (SI). As shown in Figure $\mathrm{S} 1$, when the $0.1 \mathrm{~mol} \cdot \mathrm{L}^{-1} \mathrm{NaOH}$ solution was used as the support electrolyte, the oxidation peak current of the glucose was the largest. Therefore, the 0.1 $\mathrm{mol} \cdot \mathrm{L}^{-1} \mathrm{NaOH}$ solution was used as an electrolyte for the electrochemical experiments.

Glucose sensing mechanism at $\mathrm{Ni}(\mathrm{OH})_{2} / \mathrm{CS} / \mathrm{Pt} / \mathrm{GCE}$ is explained in literature. ${ }^{34,35}$ In brevity, $\mathrm{Ni}(\mathrm{OH})_{2}$ loses

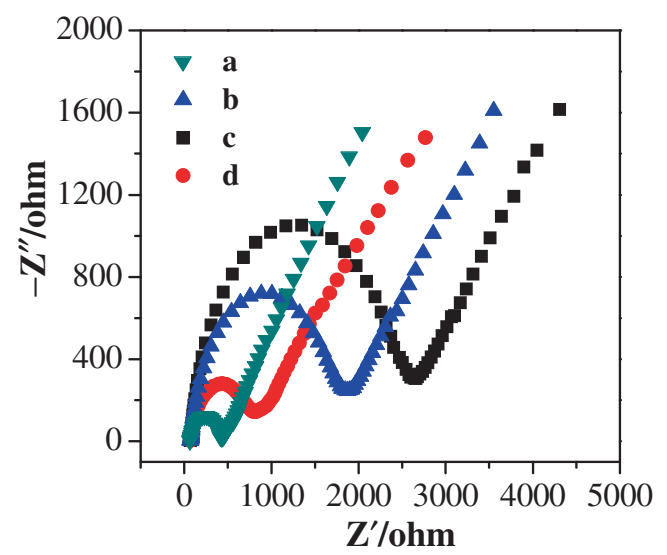

Figure 3. Nyquist plots of (a) the bare GCE, (b) $\mathrm{Ni}(\mathrm{OH})_{2} /$ GCE, (c) $\mathrm{Ni}(\mathrm{OH})_{2} / \mathrm{CS} / \mathrm{GCE}$ and (d) $\mathrm{Ni}(\mathrm{OH})_{2} / \mathrm{CS} / \mathrm{Pt} / \mathrm{GCE}$ in $0.10 \mathrm{~mol} \mathrm{~L}^{-1} \mathrm{NaOH}$ solution containing $5.0 \mathrm{mM}[\mathrm{Fe}$ $\left.(\mathrm{CN})_{6}\right]^{4-/ 3-}$ at open-circuit potential conditions (AC amplitude: $5.0 \mathrm{mV}$ ). 

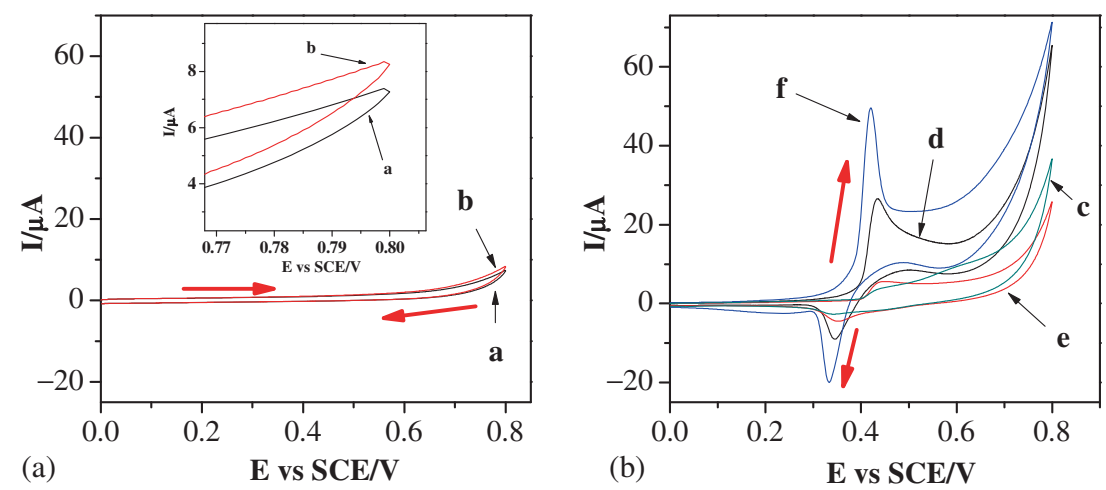

Figure 4. CVs obtained by (a, b) bare GCE, (c, d) $\mathrm{Ni}(\mathrm{OH})_{2} / \mathrm{GCE}$ and $(\mathrm{e}, \mathrm{f})$ $\mathrm{Ni}(\mathrm{OH})_{2} / \mathrm{CS} / \mathrm{Pt} / \mathrm{GCE}$ in $0.1 \mathrm{M} \mathrm{NaOH}$ solution in the absence (a, $\mathrm{c}$ and d) and presence $(\mathrm{b}, \mathrm{e}$ and $\mathrm{f})$ of $3.0 \mathrm{mM}$ glucose at a scan rate of $0.1 \mathrm{~V} / \mathrm{s}$.

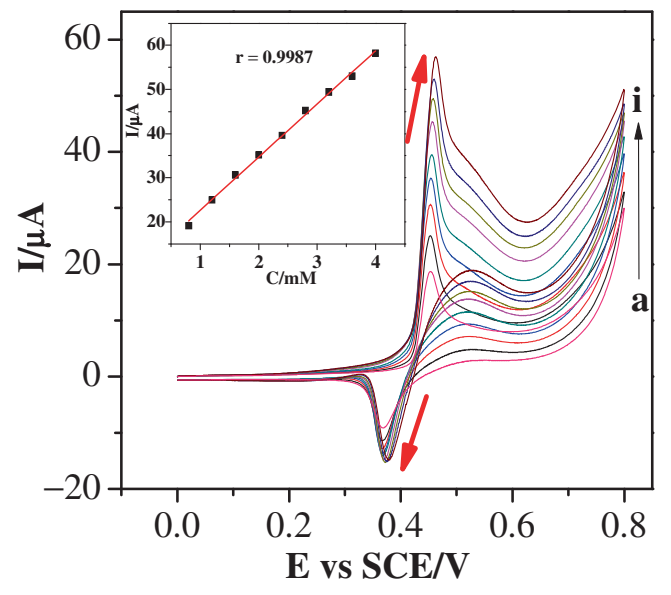

Figure 5. $\mathrm{CVs}$ obtained by $\mathrm{Ni}(\mathrm{OH})_{2} / \mathrm{CS} / \mathrm{Pt} / \mathrm{GCE}$ in the presence of different glucose concentrations ( from a to i: 0.8 , $1.2,1.6,2.0,2.4,2.8,3.2,3.6$ and $4.0 \mathrm{mM}$ ) in $0.1 \mathrm{M} \mathrm{NaOH}$ solution at a scan rate of $0.1 \mathrm{~V} \mathrm{~s}^{-1}$. Inset: Linear fitting of the oxidation peak current with glucose concentration.

an electron to become $\mathrm{NiOOH}$ in $0.1 \mathrm{M} \mathrm{NaOH}$ solution meanwhile, the rapid transfer of electrons through $\mathrm{Pt}$ NPs. Once glucose diffuses to the surface of $\mathrm{Ni}(\mathrm{OH})_{2} /$ $\mathrm{CS} / \mathrm{Pt} / \mathrm{GCE}$, it is rapidly oxidized to glucolactone by the $\mathrm{NiOOH}$ on the surface of the modified electrode, and the equations are shown as follows: ${ }^{35}$

$$
\mathrm{Ni}(\mathrm{OH})_{2}+\mathrm{OH}^{-} \Leftrightarrow \mathrm{NiOOH}+\mathrm{e}^{-}+\mathrm{H}_{2} \mathrm{O}
$$

$\mathrm{NiOOH}+$ glucose $\rightarrow \mathrm{Ni}(\mathrm{OH})_{2}+$ glucolactone

The peak current of glucose oxidation at the $\mathrm{Ni}(\mathrm{OH})_{2} / \mathrm{CS} / \mathrm{Pt} / \mathrm{GCE}$ increases with glucose concentration, as shown in Figure 5. With the gradual addition of glucose, the catalytic responses increased linearly with a correlation coefficient of $0.9987(n=9)$, proving that the $\mathrm{Ni}(\mathrm{OH})_{2} / \mathrm{CS} / \mathrm{Pt}$ nanocomposites had remarkable electrocatalytic performance towards the oxidation of glucose. The $\mathrm{Ni}(\mathrm{OH})_{2}$-based sensors have excellent catalytic performance for the oxidation of glucose in

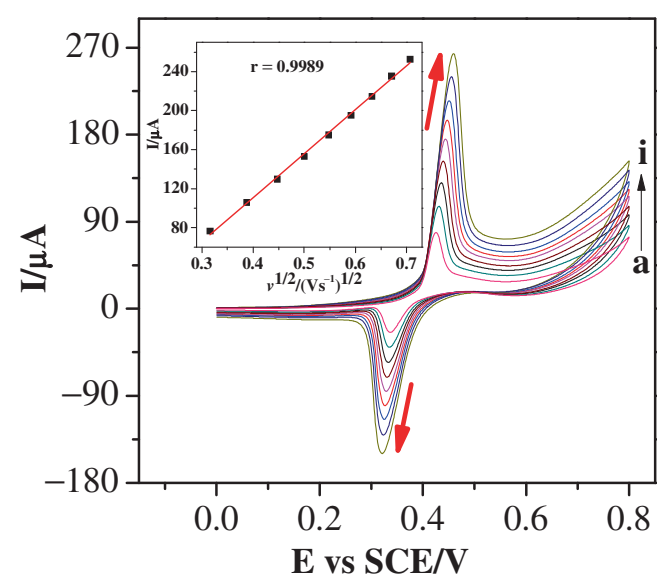

Figure 6. CVs obtained by the $\mathrm{Ni}(\mathrm{OH})_{2} / \mathrm{CS} / \mathrm{Pt} / \mathrm{GCE}$ in 0.1 $\mathrm{M} \mathrm{NaOH}$ solution containing $3.0 \mathrm{mM}$ glucose at different scan rates (from a to i: $0.10,0.15,0.20,0.25,0.30,0.35$, $\left.0.40,0.45,0.50 \mathrm{~V} \mathrm{~s}^{-1}\right)$. Inset: Linear fitting of oxidation peak current of glucose versus $v^{1 / 2}$.

an alkaline solution owing to the redox pair of $\mathrm{Ni}(\mathrm{OH})_{2} /$ $\mathrm{NiOOH}$ in which $\mathrm{NiOOH}$ can be reduced by glucose easily. ${ }^{33}$ Also, this can be attributed to the fact that $\mathrm{Ni}(\mathrm{OH})_{2}$ exhibited good catalytic properties towards the oxidation of glucose and the Pt NPs enhanced the electron transfer efficiency.

The oxidation peak currents at different scan rates with $3.0 \mathrm{mM}$ glucose are displayed in Figure 6. The oxidation peak current increased when the scan rate $(v)$ was gradually increased from 0.1 to $0.5 \mathrm{~V} \mathrm{~s}^{-1}$. The oxidation peak current shows a linear relationship with the square root of scan rate $(r=0.9989, \mathrm{n}=9)$. As shown in Figure 6 (inset), the fitting equation is $I_{p a}(\mu \mathrm{A})=40.65+436.63 v(\mathrm{r}=0.9989, \mathrm{n}=9)$, which adheres to the Randles-Sevcik equation: $I_{\mathrm{p}}=$ $0.4463 n^{3 / 2} F^{3 / 2} A D_{\text {app }}^{1 / 2} C v^{1 / 2} /(R T)^{1 / 2} .^{36,37}$ Here, $n$ is the number of electron transfer, $F$ is the Faraday's constant, $A$ is the effective surface area of the electrode, $C$ is 
the concentration of effective electroactive site, $R$ is the ideal gas constant $\left(8.314 \mathrm{~J} \cdot \mathrm{mol}^{-1} \cdot \mathrm{K}^{-1}\right), T$ is the experimental temperature $(298.15 \mathrm{~K})$ and $D_{\text {app }}$ is the apparent electron diffusion coefficient. ${ }^{37}$ According to the slope of the $I_{\mathrm{p}}-v^{1 / 2}$ line and the Randles-Sevcik equation, $D_{\text {app }}$ can be accurately calculated in this study. Thus, the oxidation of glucose on the $\mathrm{Ni}(\mathrm{OH})_{2} / \mathrm{CS} / \mathrm{Pt} / \mathrm{GCE}$ is a diffusion-controlled process.

The electron transfer number $(n)$ can be calculated by the Laviron's equations: ${ }^{38,39}$

$$
\begin{gathered}
I_{p a}=n^{2} F^{2} A \Gamma v / 4 R T \\
\Gamma=Q / n F A
\end{gathered}
$$

Here, $F$ is the Faraday constant, $A$ is the effective surface area of GCE, $\Gamma$ is the surface concentration of electroactive species, $R$ is gas constant under ideal condition, $T$ is $298.15 \mathrm{~K}$ in this study. The CVs of the

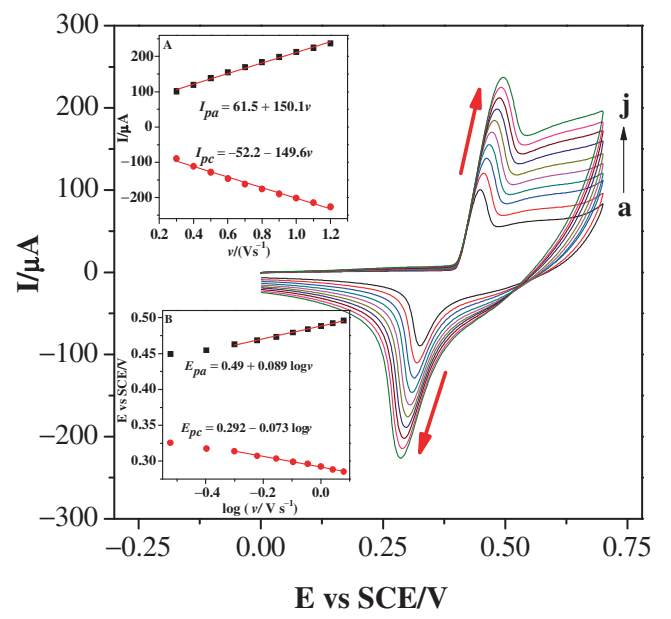

Figure 7. $\mathrm{CV}$ s obtained by the $\mathrm{Ni}(\mathrm{OH})_{2} / \mathrm{CS} / \mathrm{Pt} / \mathrm{GCE}$ in 0.1 $\mathrm{M} \mathrm{NaOH}$ solution at different scan rates (from a to $\mathrm{j}: 0.3$, $0.4,0.5,0.6,0.7,0.8,0.9,1.0,1.1$ and $\left.1.2 \mathrm{~V} \mathrm{~s}^{-1}\right)$. Inset: (A) Linear fitting of peak current versus $v$; (B) Linear fitting of peak potential versus $\log v$.
$\mathrm{Ni}(\mathrm{OH})_{2} / \mathrm{CS} / \mathrm{Pt} / \mathrm{GCE}$ in $0.1 \mathrm{M} \mathrm{NaOH}$ solution at different scan rates are shown in Figure 7. As indicated in Figure 7A, the relationship of $I_{p a}$ and $I_{p c}$ with $v$ were observed to be linear as per equations: $I_{p c} / \mu \mathrm{A}=-52.2$ $-149.6 v(\mathrm{r}=0.9986, \mathrm{n}=10)$ and $I_{p a} / \mu \mathrm{A}=61.5$ $+150.1 v(\mathrm{r}=0.9991, \mathrm{n}=10)$. These results indicate that the well-defined redox process was observed. Moreover, the $n$ was calculated as 0.91 from the slope of the $I_{p a}-\mathrm{v}$ plot, suggesting that one electron transfer has occurred. The heterogeneous electron transfer rate constant $\left(k_{s}\right)$ on $\mathrm{Ni}(\mathrm{OH})_{2} / \mathrm{CS} / \mathrm{Pt} / \mathrm{GCE}$ is evaluated using the following equations: ${ }^{40}$

$$
\begin{aligned}
& E_{p c}=E^{0^{\prime}}-\frac{R T}{\alpha n F} \log v \\
& E_{p a}=E^{0^{\prime}}+\frac{R T}{(1-\alpha) n F} \log v \\
& \log k_{s}=\alpha \log (1-\alpha)+(1-\alpha) \log \alpha \\
& -\log (R T / n F v) \\
& -(1-\alpha) \alpha F \Delta E_{p} /(2.3 R T)
\end{aligned}
$$

Here, $\alpha$ is the charge transfer coefficient, $\Delta E_{p}$ is the peak to peak potential separation and the other symbolic representations are the same as in the equations (3) and (4). As illustrated in Figure 7B, good linear relationships of $E_{p a}$ and $E_{p c}$ with $\log v$ were observed. The $\alpha$ was calculated as 0.33 by the Eqs. 5 and 6 . Further, according to the Eq. 7 , the $k_{s}$ was estimated to be $0.69 \mathrm{~s}^{-1}$, which is larger than that of 3,3'-dithiobissulfocinnimidylpropionate modified gold electrode. ${ }^{41}$ These results illustrate that the $\mathrm{Ni}(\mathrm{OH})_{2} / \mathrm{CS} / \mathrm{Pt}$ is conducive to enhancing the electron transfer efficiency.

Figure 8A shows the amperometric responses of different glucose concentrations at the $\mathrm{Ni}(\mathrm{OH})_{2} / \mathrm{CS} /$ $\mathrm{Pt} / \mathrm{GCE}$ in $0.1 \mathrm{M} \mathrm{NaOH}$ with the applied potential of 0.5 $\mathrm{V}$. Figure $8 \mathrm{~B}$ shows the calibration plot obtained for the sensor. Here, $\mathrm{Ni}(\mathrm{OH})_{2} / \mathrm{CS} / \mathrm{Pt} / \mathrm{GCE}$ shows the amperometric response for glucose within $4 \mathrm{~s}$, indicating a fast
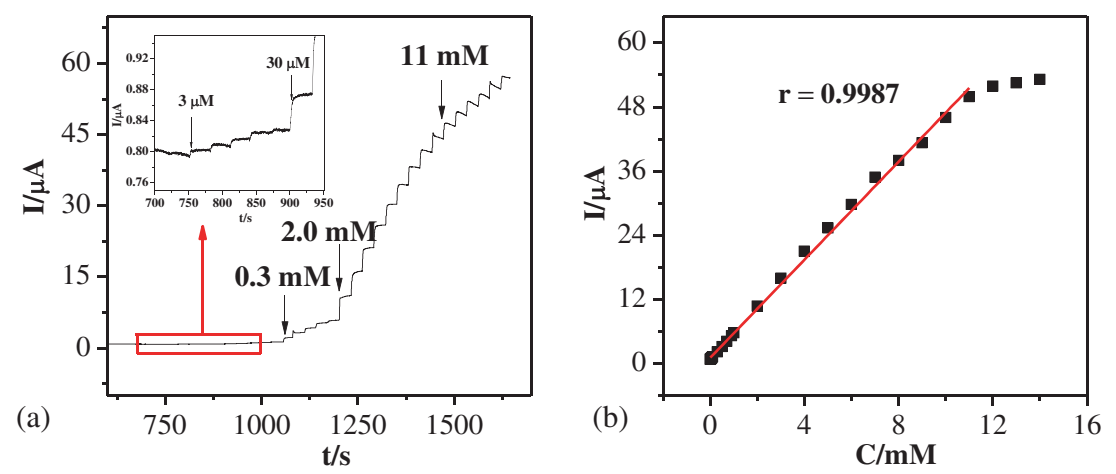

Figure 8. (A) Amperometric response obtained by the $\mathrm{Ni}(\mathrm{OH})_{2} / \mathrm{CS} / \mathrm{Pt} / \mathrm{GCE}$ upon successive injection of glucose in $0.1 \mathrm{M} \mathrm{NaOH}$ solution with the applied potential of $0.5 \mathrm{~V}$. (B) Calibration plot of glucose versus concentration. 
response. The linear detection range is from 0.003 to $11 \mathrm{mM}$ with a correlation coefficient of 0.9987 ( $\mathrm{n}=$ 28 ), the sensitivity is $64.83 \pm 0.12 \mu \mathrm{A} \mathrm{mM}^{-1} \mathrm{~cm}^{-2}$ and the detection limit is $0.56 \pm 0.03 \mu \mathrm{M}$ at a signal-tonoise ratio of 3 . Based on these good analytical performance, we can conclude that the $\mathrm{Ni}(\mathrm{OH})_{2} / \mathrm{CS} / \mathrm{Pt}$ nanocomposites have a significant effect on the oxidation of glucose because of their good conductivity and catalytic properties. Moreover, a comparison of some important analytical performance of our sensor with other nonenzymatic electrochemical glucose sensors are listed in Table 1. It was noticeable that our sensor has a wide linear range, acceptable sensitivity and a low detection limit. It may be because of the excellent electrocatalytic properties of $\mathrm{Ni}(\mathrm{OH})_{2} / \mathrm{CS} / \mathrm{Pt}$ nanocomposites for the oxidation of glucose.

\subsection{Reproducibility and stability study}

The reproducibility and stability of the $\mathrm{Ni}(\mathrm{OH})_{2} / \mathrm{CS} /$ $\mathrm{Pt} / \mathrm{GCE}$ are crucial for the electrochemical experiments. A relative standard deviation of $3.0 \%$ was obtained based on five successive amperometric responses of a $\mathrm{Ni}(\mathrm{OH})_{2} / \mathrm{CS} / \mathrm{Pt} / \mathrm{GCE}$ at $0.5 \mathrm{~V}$, indicating that this glucose sensor has a good reproducibility. The stability of $\mathrm{Ni}(\mathrm{OH})_{2} / \mathrm{CS} / \mathrm{Pt} / \mathrm{GCE}$ was also evaluated. Three $\mathrm{Ni}(\mathrm{OH})_{2} / \mathrm{CS} / \mathrm{Pt} / \mathrm{GCEs}$ were used to detect glucose in $0.1 \mathrm{M} \mathrm{NaOH}$ solution after storing these working electrodes in a fridge of $4^{\circ} \mathrm{C}$ for four weeks. An average of more than $90 \%$ of the initial amperometric responses was obtained. The test results are listed in Table S1 in Supplementary Information. To sum up, the $\mathrm{Ni}(\mathrm{OH})_{2} /$ CS/Pt/GCE possessed acceptable reproducibility and stability.

\subsection{Interference study}

The anti-interference performance of the sensor has a significant impact on its application in complex conditions; in view of that, the study on the anti-interference of the sensor is valuable. The amperometric responses of the $\mathrm{Ni}(\mathrm{OH})_{2} / \mathrm{CS} / \mathrm{Pt} / \mathrm{GCE}$ upon the injection of glucose, other electroactive species and dissolved oxygen $\left(\mathrm{O}_{2}\right)$ in $0.1 \mathrm{M} \mathrm{NaOH}$ solution under stable stirring condition with the applied potential of $0.5 \mathrm{~V}$ are shown in Figure 9. As seen in Figure 9, the amperometric current was not changed obviously when ascorbic acid (AA), uric acid (UA), dopamine (DA), $\mathrm{NaCl}$ and hydrogen peroxide $\left(\mathrm{H}_{2} \mathrm{O}_{2}\right)(1.0 \mathrm{mM}$, respectively) were added. Meanwhile, $\mathrm{O}_{2}$ was also added to the system as a possible interfering species. Pure oxygen $(99.99 \%)$ was passed into the $0.1 \mathrm{M} \mathrm{NaOH}$ solution through a plastic tube (1 mm in diameter). This process lasted for $30 \mathrm{~s}$. The concentration of dissolved oxygen is about 3.2 $\mathrm{mg} / \mathrm{mL}$. On the basis of these results, we concluded that this sensor exhibited a favourable anti-interference ability to other common electroactive species and dissolved oxygen in the blood.

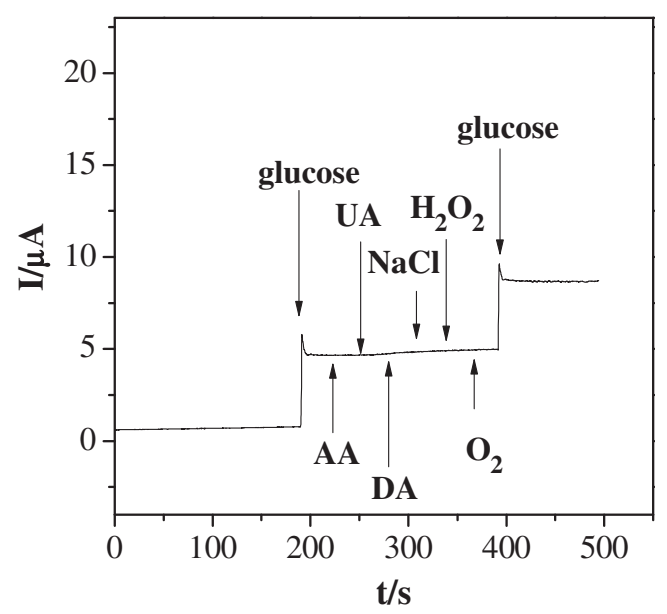

Figure 9. Amperometric responses obtained by the $\mathrm{Ni}(\mathrm{OH})_{2} / \mathrm{CS} / \mathrm{Pt} / \mathrm{GCE}$ to successive addition of glucose, ascorbic acid (AA), uric acid (UA), dopamine (DA), $\mathrm{NaCl}$ and hydrogen peroxide $\left(\mathrm{H}_{2} \mathrm{O}_{2}\right)\left(1.0 \mathrm{mM}\right.$, respectively) and $\mathrm{O}_{2}$ $(3.2 \mathrm{mg} / \mathrm{mL})$ in $0.1 \mathrm{M} \mathrm{NaOH}$ solution under stirring conditions with the applied potential of $0.5 \mathrm{~V}$.

Table 1. Comparison of analytical performance of the proposed glucose sensor with other non-enzymatic glucose sensors.

\begin{tabular}{|c|c|c|c|c|}
\hline Sensors & Linear range (mM) & Sensitivity $\left(\mu \mathrm{AmM}^{-1} \mathrm{~cm}^{-2}\right)$ & Detection limit $(\mu \mathrm{M})$ & References \\
\hline$(\mathrm{Ag} @ \mathrm{MH} / \mathrm{MWCNT})^{\mathbf{a}}$ & $0.001-350$ & - & 0.0003 & 7 \\
\hline$(\mathrm{GE}-\mathrm{Ni} \text { NPs/GCE) })^{\mathbf{b}}$ & $0.001-1$ & - & 0.474 & 33 \\
\hline $\mathrm{RGO}-\mathrm{Ni}(\mathrm{OH})_{2} / \mathrm{GCE}$ & $0.002-3.1$ & 11.43 & 0.6 & 42 \\
\hline MWCNT/NiO/GCE & $0.2-12$ & - & 160 & 43 \\
\hline Porous Au/GCE & $2-10$ & 11.80 & 5 & 44 \\
\hline Ni-MWCNT/GCE & $3.2-17.5$ & 67.19 & 0.98 & 45 \\
\hline $\mathrm{Pt} / \mathrm{N}-\mathrm{GSS} / \mathrm{GCE}$ & $0.01-12.55$ & 22.51 & 1 & 46 \\
\hline $\mathrm{Ni}(\mathrm{OH})_{2} / \mathrm{CS} / \mathrm{Pt} / \mathrm{GCE}$ & $0.003-11$ & $64.83 \pm 0.12$ & $0.56 \pm 0.03$ & This work \\
\hline
\end{tabular}

-not provided; a silver nanoparticles decorated metformin functionalized multi-wall carbon nanotube; ${ }^{\mathbf{b}}$ graphene-NiNP hybrid modified magnetic electrode; ${ }^{\mathbf{c}}$ graphene nanoscrolls. 
Table 2. Detection results of glucose in the blood serum samples by the standard addition method. $\left(\mathrm{n}=3^{*}\right)$

\begin{tabular}{lccc}
\hline Sample & Glucose added $(\mathrm{mM})$ & Glucose found $(\mathrm{mM})$ & Recovery $(\%)$ \\
\hline blood serum sample & - & $0.126( \pm 0.03)$ & - \\
Sample 1 & 0.1 & $0.224( \pm 0.05)$ & 99.1 \\
Sample 2 & 0.8 & $0.929( \pm 0.03)$ & 100.3 \\
Sample 3 & 2.5 & $2.631( \pm 0.02)$ & 100.2 \\
\hline
\end{tabular}

*Average of three determinations ( \pm relative standard deviation).

\subsection{Blood serum analysis}

The ability of this glucose sensor for real sample analysis was tested in blood serum samples using the standard addition method. The blood serum samples were provided by Xi'an Medical University (Xi'an, China). In a typical case, the blood serum sample $(1.0 \mathrm{~mL})$ was added to $9.0 \mathrm{~mL}$ of $0.1 \mathrm{M} \mathrm{NaOH}$ solution and the concentration of glucose was calculated based on the amperometric current response. The results recorded by using the $\mathrm{Ni}(\mathrm{OH})_{2} / \mathrm{CS} / \mathrm{Pt} / \mathrm{GCE}$ are in good agreement with the values obtained by a commercial blood glucose meter (Roche Accu-Chek Performa, Germany). The recorded results are listed in Table 2. As seen in Table 2, the recoveries from 99.1 to $100.3 \%$ and the calculated relative standard deviation within $0.05 \mathrm{mM}$ suggest that this glucose sensor can be used for detecting glucose in real samples.

\section{Conclusions}

In summary, $\mathrm{Ni}(\mathrm{OH})_{2} / \mathrm{CS} / \mathrm{Pt}$ nanocomposite was successfully synthesized by using chtosan (CS) as a dispersing and protecting agent. Further, a non-enzymatic glucose sensor based on the $\mathrm{Ni}(\mathrm{OH})_{2} / \mathrm{CS} / \mathrm{Pt}$ nanocomposite was found to present good electrocatalytic ability towards the oxidation of glucose. This sensor can be used for the detection of glucose with high sensitivity and good selectivity. It also exhibited a wide linear range and low detection limit. Moreover, the developed sensor was successfully applied to detect glucose in real serum samples. Based on these excellent results this study may provide a feasible approach to develop new non-enzymatic electrochemical sensors for the detection of other electroactive species.

\section{Supplementary Information (SI)}

The effect of concentration of $\mathrm{NaOH}$ solution on the oxidation peak current of glucose and Table S1 are shown in the Supplementary Information which is available at www.ias.ac.in/chemsci.

\section{Acknowledgements}

The authors gratefully acknowledge the financial support for this project by the National Science Foundation of China (No. 21575113 and No. 21275116), Specialized Research Fund for the Doctoral Program of Higher Education (No. 20126101110013), the Natural Science Foundation of Shaanxi Province in China (No. 2013KJXX-25) and the Scientific Research Foundation of Shaanxi Provincial Key Laboratory (13JS098, 14JS094, 15JS100).

\section{References}

1. Chen C, Xie Q J, Yang D W, Xiao H L, Fu Y C, Tan Y M and Yao S Z 2013 RSC Adv. 34473

2. Dutta A K, Das S, Samanta S, Samanta P K, Adhikary B and Biswas P 2013 Talanta 107361

3. Cheng Z L, Wang E K and Yang X R 2001 Biosens. Bioelectron. 16179

4. Yang P, Jin S Y, Xu Q Z and Yu S H 2013 Small 9199

5. Zhai D Y, Liu B R, Shi Y, Pan L J, Wang Y Q, Li W B, Zhang R and Yu G H 2013 ACS Nano. 73540

6. Fang L X, Liu B, Liu L L, Li Y H, Huang K J and Zhang Q Y 2016 Sens. Actuators, B 2221096

7. Baghayeri M, Amiri A and Farhadi S 2016 Sens. Actuators, $B 225354$

8. Li L M, Du Z F, Liu S, Hao Q Y, Wang Y G, Li Q H and Wang T H 2010 Talanta 821637

9. Long L H, Hoi A and Halliwell B 2010 Arch. Biochem. Biophys. 501162

10. Rao D J, Zhang J and Zheng J B 2016 J. Chem. Sci. 128 839

11. Felix S, Kollu P, Raghupathy B P, Jeong S K and Grace A N 2014 J. Chem. Sci. 12625

12. Wu G H, Song X H, Wu Y F, Chen X M, Luo F and Chen X 2013 Talanta 105379

13. Badhulika S, Paul R K, Terse T and Mulchandani A 2014 Electroanal. 26103

14. Yu Y Y, Chen Z G, He S J, Zhang B B, Li X C and Yao M 2014 Biosens. Bioelectron. 52147

15. Mazeiko V, Kausaite-Minkstimiene A, Ramanaviciene A, Balevicius Z and Ramanavicius A 2013 Sens. Actuators, B 189187

16. Wang C, deKrafft K E and Lin W 2012 J. Am. Chem. Soc. 1347211 
17. Matsumoto $\mathrm{H}$, Tanji $\mathrm{T}$, Amezawa $\mathrm{K}$, Kawada $\mathrm{T}$, Uchimoto Y, Furuya Y and Ishihara T 2011 Solid State Ionics 18213

18. Yu Y Y, Yang Y, Gu H, Zhou T S and Shi G Y 2013 Biosens. Bioelectron. 41511

19. Colvin A E and Jiang H 2013 J. Biomed. Mater. Res. A 1011274

20. Gowthaman N S K and John S A 2016 J. Chem. Sci. 128 331

21. Guo S J and Wang E K 2011 Nano Today 6240

22. Martins P R, Aparecida Rocha M, Angnes L, Eisi Toma H and Araki K 2011 Electroanal. 232541

23. Tan Y, Srinivasan S and Choi K S 2005 J. Am. Chem. Soc. 1273596

24. Chen J and Zheng J B 2015 J. Electrochem. Chem. 749 83

25. Mesbah Namini S M, Mohsenifar A, Karami R, Rahmani-Cherati T, Shojaei T R and Tabatabaei M 2015 Chem. Pap. 691291

26. Dash M, Chiellini F, Ottenbrite R M and Chiellini E 2011 Prog. Polym. Sci. 36981

27. Rabea E I, Badawy M E T, Stevens C V, Smagghe G and Steurbaut W 2003 Biomacromolecules 41457

28. Kumar M N R 2000 React. Funct. Polym. 461

29. Lian W J, Liu S, Yu J H, Xing X R, Li J, Cui M and Huang J D 2012 Biosens. Bioelectron. 38163

30. Bai Z Y, Zhou C L, Gao N, Pang H J and Ma H Y 2016 RSC Adv. 6937

31. Prathap M A, Anuraj V, Satpati B and Srivastava R 2013 J. Hazard. Mater. 262766
32. Mano N, Mao F and Heller A 2003 J. Am. Chem. Soc. 1256588

33. Qu W D, Zhang L Y and Chen G 2013 Biosens. Bioelectron. 42430

34. Yuan J H, Wang K and Xia X H 2005 Adv. Funct. Mater. 15803

35. Safavi A, Maleki N and Farjami E 2009 Biosens. Bioelectron. 241655

36. Wang J Y, Chen L C and Ho K C 2013 ACS Appl. Mater. Inter. 57852

37. Majdi S, Jabbari A, Heli H, Yadegari H, MoosaviMovahedi A A and Haghgoo S 2009 J. Solid State Electrochem. 13407

38. Laviron E 1979 J. Electroanal. Chem. Interface 100263

39. Zhang Y H, Chen X and Yang W S 2008 Sens. Actuators, $B \mathbf{1 3 0} 682$

40. Laviron E 1979 Electroanal. Chem. 10119

41. Jiang L, McNeil C J and Cooper J M 1995 J. Chem. Soc. Chem. Commun. 121293

42. Zhang Y, Xu F G, Sun Y J, Shi Y, Wen Z W and Li Z 2011 J. Mater. Chem. 2116949

43. Shamsipur M, Najafi M and Hosseini M R M 2010 Bioelectrochemistry 77120

44. Li Y, Song Y Y, Yang C and Xia X H 2007 Electroanal. Chem. 9981

45. Sun A L, Zheng J B and Sheng Q L 2012 Electrochim. Acta 6564

46. Meng L Y, Xia Y X, Liu W G, Zhang L, Zou P and Zhang Y S 2015 Electrochim. Acta 152330 